\title{
Thinking on the Construction of Intellectual Property System with Chinese Characteristics under the Perspective of Marxism Theory
}

\author{
Yanying Fei \\ Faculty of Humanities and Social Sciences \\ Dalian University of Technology \\ Dalian, China
}

\author{
Liang Zhao \\ School of Marxism \\ Dalian University of Technology \\ Dalian, China
}

\begin{abstract}
The western intellectual property system has existed for several centuries and it has become a perfect system. With the establishment of new China, Chinese intellectual property system has gradually developed too. It is currently in the new period of building the intellectual property system with Chinese characteristics. The article analyses the intellectual property system, demonstrating the necessity of the existence of intellectual property system with Chinese characteristics and puts forward the basic idea of the construction of intellectual property system with Chinese characteristics under the perspective of Marxism theory.
\end{abstract}

Keywords-Chinese characteristics; intellectual property system; marxism theory

\section{INTRODUCTION}

The modern intellectual property system is originated in Britain in the 13th century. The king of England rewarded technological innovators with an imperial edict to encourage the subjects to carry out the technological innovation at that time. Such edict is called "letter patent" so that the system is called public certificate system by scholars. In the 15th century, the Venetian city-state enacted the first patent law. It has taken a step forward in the standardization and legalization of intellectual property. After the industrial revolution, technology has played an unprecedented role in boosting productivity with the rise of the capitalist mode of production. Major capitalist countries such as the United States, Spain, Germany and other countries have developed the legal system of intellectual property to protect technology patent. Comparatively speaking, the Chinese ancient folk craftsman also can invent the unique technology in the domestic operation. But all these techniques are proud of that it was used by the imperial family only. The inheritance of the system often exists in the relatives of direct lineal, which is usually taught to male not female so that it fails to form a systematic protection system. The national government has formulated the temporary articles of association for the award of arts and crafts, provisional regulations for the award of industrial technology and provisional regulations for the award of industrial products. The first Chinese patent law was enacted in 1944. However, the corresponding legal provisions are difficult to implement due to the long war status so it is limited in promoting the development of science and technology. The nation abolished the old systems after the establishment of new China and had enacted laws and regulations on intellectual property such as the interim regulations on the protection of invention and patent right as well as incentive ordinance of invention. Deng Xiaoping put forward that science and technology are the first productive force after the reform and opening up. Under the guidance of this thought, the standing committee of the National People's Congress enacted the first patent law of new China to protect the technological innovation in 1984. The patent law is undergoing its fourth amendment at the present time. With the intellectual property system maturing, we need to use Marxism theory to analyze it, recognizing nature and construct the intellectual property system with Chinese characteristics.

\section{THE THEORETICAL ANALYSIS OF INTELLECTUAL} PROPERTY SYSTEM UNDER THE PERSPECTIVE OF MARXISM THEORY

\section{A. Intellectual Property is a Special Commodity}

Marx thought that commodity is an external object and a thing that satisfies personal needs by their properties. Specifically, commodities are labor products that are exchanged which have use value and value. Is intellectual property a commodity? This is a very important question which concerns whether intellectual property can be exchanged in the commodity economy. The author thinks that intellectual property is commodity. But it is a special commodity. Reason follows: firstly, intellectual property has use value. Technology is the main engine driving human development in modern society. The producer can make a forward in their production efficiency when they have mastered a particular patented technology that is far more meaningful to the producer than the materialized production equipment. According to the intellectual property law in our country, many high technologies exist in the form of intellectual property liking patent. Therefore, intellectual property can meet human needs which have use value; Secondly, intellectual property has value. Intellectual property just as its name implies is property rights of 
intellectual. The content of intellectual property is mainly science and technology which is the "product" of the inventor through complex type of labor that contained the undifferentiated human labor. So that intellectual property has value certainly; thirdly, intellectual property is a special commodity. Because of the limitations of the times, Marx talked about the tangible goods. But intellectual property is the intangible goods which has the general properties of commodities and can be transferred according to law.

\section{B. Intellectual Property System Belongs to the Category of Ideology}

Engels points out that any ideology is developed with the combination of existing conceptual materials and makes it further processing. The intellectual property system was born in the capitalist mode of production which has a capitalist ideology naturally. The bourgeoisie pays great attention to the labor potential of the workers in order to maximize the residual value in the capitalist society. As a result, workers on the surface have benefited more from the intellectual property system. But the essence is bourgeoisie has multiplied the surplus value. In addition, intellectual property as a special commodity has tremendous development speed and huge development space. It has become one of the most important commodities in the market economy and greatly deepens the level of commodity fetishism in the capitalist society. With the expansion of the intellectual property system in the economic field, it gradually evolved into money worship and capital fetishism. The hegemony of intellectual property in western countries represented by the United States is also expanding in international economic activity. Because western countries are far ahead of developing countries in science and technology, it ignores the reality of countries and maliciously enhances the level of intellectual property protection in the international intellectual property convention and national laws to serve their own interests. It has increased the burden on developing countries. In addition, it provides opportunities of intellectual property to developing countries by themselves and forces out the country's political system, economic model and cultural habit that affects the speed of economic development as well as causes confusion in the minds of people in developing countries. Therefore, the intellectual property system is a seemingly fair and reasonable "universal system". In fact, it has a deep ideological imprint.

\section{Intellectual Property System Has Legal Property}

As mentioned above, the source of the intellectual property system, public certificate system is imperial edict so that it has legal properties at first. After that, the intellectual property system was closely combined with law in several centuries. The relevant intellectual property is protected only within the limits of domestic law. Otherwise it can be used in the public domain optionally, because intellectual property is the innovation on the basis of common intellectual achievement of mankind which has the properties of common resource so that it can't be easily restricted for use. However, in order to encourage the public to continuously carry out independent innovation and promote social development, the government has passed laws that allow for "exclusivity" within a certain period of time. It gives the right holder the corresponding economic benefit. In order to prevent the intellectual property system from being overused, relevant laws have "compulsory license" and other provisions such as intellectual property rights involving national security can be used in an emergency without the consent of the oblige. In addition, intellectual property is not protected by the country's intellectual property system in foreign countries. But there are some binding international treaties on intellectual property such as the Paris convention on the protection of industrial property and trade-related intellectual property agreements and so on. All high contracting parties are subject to treaty regulation so that the intellectual property system breaks the regional limits. To sum up, we can see that the intellectual property system can be carried out smoothly under the legal protection of the coercive force of the country. So the intellectual property system has legal properties.

\section{THE NECESSITY OF INTELLECTUAL PROPERTY SYSTEM WITH CHINESE CHARACTERISTICS UNDER THE PERSPECTIVE OF MARXISM THEORY}

Although the intellectual property system was born in the western capitalist countries, it had introduced to China for many years and grounded. It has made great contributions to ensuring scientific, technological progress and economic development. In this context, discuss the necessity of the existence of intellectual property system with Chinese characteristics is senseful or not? I think the answer is yes. The intellectual property system is a foreign product to play a major role in Chinese economic development and really forms Chinese characteristics. We must use Chinese guiding theory to interpret and judge. It will clarify the intellectual property system's strategic position.

\section{A. Complex Labor must be Involved in Commodity Production}

Marx thought that "The production of goods not only reflects economic relations, it reflects the social relations between people." The process of commodity production is labor works on production data and finally forms a production form of labor products. At first, commodity production mainly is simple labor and production data combination into labor products. However, with the development of productivity, especially since the emergence of the capitalist mode of production, the technological level of the human race is constantly improving. The combination of complex labor and production data is increasing. It's even becoming dominant. Marx pointed out that "The development of capitalist production is bound to lead to the separation of science and labor and also to the application of science to material production." Here below in science and technology is the laborer after complex labor created, it contains human indifference labor and its value is simple the several times of labor, the value of goods but also qualitative changes have taken place. Our country socialist market economy commodity production way and capitalism have essentially different, but with the development of productivity, in the production of goods the same in a lot of 
complicated work, these complex labor, in science and technology form has great value. We must confront it and establish a sound system to protect the goods created by this complex labor. Establishing the system of intellectual property according to law, make the most of the modern commodity production complex labor in intellectual property form as an independent commodity trading in the market, conforms to the law of development of market economy.

\section{B. The Development of Socialist Market Economy Depends on Science and Technology}

Marx once proposed "Technology is productive". At the beginning of the reform and opening up, Deng Xiaoping pointed out that "science and technology is the first productive force", which is the inheritance and development of Marx's theory of productive forces. Therefore, under the condition of socialist market economy, it is necessary to liberate the development of productive forces and rely mainly on the development of science and technology. About encourage inventors to carry on the independent innovation system, our country implement two kinds. One is an inventor's certificate system, namely only awarded the honorary certificate, inventor and one-time give bonuses, invented property belongs to country; The other is the intellectual property system, in which the country gives the inventor the right to "monopolize" his invention during a certain period of time and the inventor proceeds through this "monopoly right" transaction. At present, under the market conditions, it is the intellectual property system that can most effectively promote the development of science and technology. Inventor through its own complex labor, labor products and intellectual property as the flow of goods in accordance with the law in the market, both to obtain economic benefits, the inventor inspired the inventor of the labor potential, and for the users to improve the efficiency of production, promoted the development of production, can be said to be a win-win situation.

The intellectual property system with Chinese characteristics, therefore, rejected the capitalist exploiting intellectual property system, grab the evil root of surplus value, the maximum play to the advantages of the intellectual property system to promote scientific and technological innovation, thus greatly promoted the development of the productive forces and meet the basic requirement of the socialist market economy.

\section{The Intellectual Property System is an Important Tool of National Governance}

At present, our country is to promote national governance system and modern governance capacity, the author thinks that state governance in short is governed, the whole country in a series of perfect system to run, "don't change by leaders of change, not because of the change of opinion leaders and attention change". Our country socialist market economy is law economy, its core is on the premise of stick to the four cardinal principles, through the perfect legal system to mobilize the enthusiasm of the broad masses of working people and realize the rapid development of the economy. At present, the engine of the world economy is innovation, and its competition is no longer the extensive competition of resource quantity and population quantity, but is completely transferred to the intellectual competition with science and technology as the core. Therefore, science and technology is a great significance to our country's development. We cannot rely solely on the self-sacrifice of the scientific and technological workers, the national moral calling or the temporary policies to promote the creation and development of science and technology. We must establish a set of perfect intellectual property system to encourage the public to carry on the independent innovation, safeguard the rights and interests at the same time, make the intellectual property system of governance is an important tool, this accords with national governance system and the inherent requirement of modern governance ability.

\section{THE BASIC IDEA OF THE CONSTRUCTION OF INTELLECTUAL PROPERTY SYSTEM WITH CHINESE CHARACTERISTICS UNDER THE PERSPECTIVE OF MARXISM THEORY}

\section{A. Encourage Independent Innovation}

"Innovation is the soul of national progress, an inexhaustible source of a country prosperous, also the Chinese nation's deep national endowment", the direct purpose of the development of the intellectual property system with Chinese characteristics is to stimulate independent innovation, the road of independent innovation with Chinese characteristics and realize the leapfrog development of science and technology. Therefore, the idea of encouraging independent innovation is the first concept of the construction of intellectual property system with Chinese characteristics. Independent innovation emphasizes the original innovation of science and technology, introduces absorption and re-innovation and rejects simple imitation. In the intellectual property system with Chinese characteristics must highlight revenue model of independent innovation, scientific and technological achievements of business operations, independent innovation achievements of main aspects for the protection of the law, in order to motivate the enthusiasm of the laborer in independent innovation, advocating innovation culture, build a kind of in the whole society good innovation atmosphere, arouse the whole nation's independent innovation vitality.

\section{B. Pay Attention to Institutional Guarantee}

A good system can be a mirage if it is not guaranteed, as the intellectual property system. The intellectual property system, though naturally associated with the law, but we also want to clarify that belongs to the intellectual property law, which belongs to the intellectual property policies, through the national force to maintain the stability of the intellectual property system and ensure the normal work. The protection of intellectual property system with Chinese characteristics is relatively perfect, including administrative protection and judicial protection. Administrative protection, that is, the competent department of intellectual property shall take the initiative to investigate the illegal acts of intellectual property in a separate or joint law enforcement manner; judicial 
protection, that is, the parties to the court to initiate litigation on intellectual property disputes. China has set up three intellectual property courts. It is necessary to pay attention to the improvement of intellectual property system so that the Chinese characteristic intellectual property system can play its due role.

\section{Emphasize the Balance of Interests}

Knowledge is the common wealth of human society. It is a kind of public resource. The establishment of intellectual property system is to stimulate independent innovation, but it cannot be an obstacle that impedes the normal propagation of knowledge. In order to prevent over-protection of intellectual property, we must emphasize the balance of interests in the construction of intellectual property system with Chinese characteristics. It has the following two meanings: to balance the interests of intellectual property owners and users. If the income of the intellectual property owner is too little, then it will affect the initiative of independent innovation, which is not conducive to scientific and technological progress. If intellectual property users pay too much, it will affect their access to intellectual property, which is not conducive to the spread of advanced technology. On the other hand, we should balance the interests between intellectual property owners and the public. It is not possible for the implementation of the intellectual property system to affect the public interest in the use of knowledge or harm the legitimate rights of the intellectual property owners on the pretext of the public interest.

\section{Having International Vision}

The intellectual property system is an exotic product so the construction of intellectual property system with Chinese characteristics must not be closed. Based on Chinese national conditions, it is necessary to have an international perspective and draw on the rich experience of the construction of intellectual property system in developed countries so as to internationalize its own intellectual property system. For this, we should do two aspects: on the one hand, the national spirit, the traditional culture of our country shall be combined with the international modern intellectual property system, making it fall to the ground to take root, truly according with the practice of our country; On the other hand, we should actively participate in the formulation of international intellectual property treaties. China must according to international intellectual property system construction to express the general demands of developing countries to prevent the western developed countries make intellectual property hegemonism and earnestly safeguard the legitimate rights and interests of developing countries.

\section{CONCLUSION}

The importance of innovation is growing with the economy enters a new normal so that we should recognize the nature of the intellectual property system, adhering to the basic concept of system construction, improving the intellectual property system with Chinese characteristics continuously, protecting innovation results and promote the implementation of innovation-driven strategy and intellectual property strategy to accelerate the construction of an innovative country.

\section{REFERENCES}

[1] Compilation and Translation Bureau of the CPC Central Committee Selections from Marx and Engels, vol. 2. Beijing: People's Publishing House, 2012

[2] Compilation and Translation Bureau of the CPC Central Committee Complete Works from Marx and Engels, vol. 21. Beijing: People's Publishing House, 1965.

[3] Compilation and Translation Bureau of the CPC Central Committee Complete Works from Marx and Engels, vol. 26. Beijing: People's Publishing House, 1974.

[4] Secretariat of the General Office of the CPC Central Committee. Deng Xiaoping Theory of Party Construction. Beijing: People's Publishing House, 1990.

[5] Literature Research Office of the CPC Central Committee. Xi Jinping's Discussion on Science and Technology Innovation. Beijing: Central Party Literature Press, 2016.

[6] Wu Handong. Intellectual Property Law, 5th ed. Beijing: Law Press, 2014. 